\title{
Niksar İlçesinin Yerel Kalkınma Açısından Cittaslow Üyelik Potansiyelinin Değerlendirilmesi ${ }^{1}$
}

\author{
Evaluation of Cittaslow Membership Potential in Terms of Local Development of \\ Niksar District
}

\author{
Rüştü YAYAR * \\ Derya ARSLAN **
}

\begin{abstract}
$\ddot{O} Z$
Sürdürülebilir kalknma yerel dinamiklerin harekete geçirilmesi ile toplumun sosyal, kültürel ve ekonomik olarak iyileşmesini amaçlar. Bu ancak, çevresel değerlerin korunması ve ekonomik kalkinma arasındaki uzlaşma ile gerçekleşebilir. Bu çalışma, Cittaslow ve SlowFood hareketinin, bir yerel kalkınma modeli olabileceği fikrini tartışmak amacı ile hazırlanmış olup Niksar ilçesini kapsamaktadır. Çalışmada Niksar'ın Cittaslow'a ait 72 kriter açısından değerlendirilmesi yapılmuştır. Değerlendirmelere sonucunda; 72 kriterin 22 tanesini sağlamayıp, 50 âdetinde ise plan ve proje bulunmaktadır. Niksar İlçesi'nin üyelik potansiyelinin pozitif olduğu tespit edilmişstir. İkinci olarak Niksar'da yaşayan kişilerin Cittaslow algılarını ve desteklemeye dair görüşlerini belirlemek için 88 kişiyle anket yapılmıştır. Verilere faktör analizi, anova ve t testi uygulanmıștır. Analiz sonucunda Niksar'ın Cittaslow unvanına sahip olmasını isteyenlerin ve Cittaslow kavramın bilme oraninın yüksek olduğunu, Niksar'da yerel kalkınmanın turizm ve yerel değerlerin tanıtımı ile să̆lanacağı fikri belirlenmiştir.
\end{abstract}

\section{ANAHTAR KELIMELER}

Sürdürülebilirlik, Yerel Kalkınma, Cittaslow, Niksar

\begin{abstract}
Sustainable development aims to improve the society socially, culturally and economically by activating local dynamics. This can only be achieved through a compromise between environmental protection and economic development. This study was prepared to discuss the idea that Cittaslow and SlowFood movement could be a model of local development and covers Niksar district. In the study, Niksar was evaluated in terms of 72 criteria belonging to Cittaslow. As a result of the evaluations; It does not meet 22 of 72 criteria, and there are plans and projects in 50 of them. It has been determined that the membership potential of Niksar District is positive. Secondly, a survey was conducted with 88 people in order to determine the perceptions of the people living in Niksar on the Cittaslow and their views on support. Factor analysis, anova and t test were applied to the data. As a result of the analysis, it was determined that those who want Niksar to have the title of Cittaslow and have a high rate of knowing the concept of Cittaslow, and that local development in Niksar will be achieved through the promotion of tourism and local values.
\end{abstract}

\section{KEYWORDS}

Sustainability, Local Development, Cittaslow, Niksar

\begin{tabular}{|c|c|c|}
\hline \multicolumn{2}{|c|}{ Makale Geliş Tarihi /Submission Date } & \multicolumn{1}{c|}{$\begin{array}{c}\text { Makale Kabul Tarihi / Date of Acceptance } \\
22.11 .2021\end{array}$} \\
\hline \multirow{3}{*}{ Atıf } & \multicolumn{2}{|c|}{$\begin{array}{l}\text { Yayar, R. ve Arslan, D. (2021). Niksar İlçesinin Yerel Kalkınma Açısından Cittaslow Üyelik Potansiyelinin } \\
\text { Değerlendirilmesi. Selçuk Üniversitesi Sosyal Bilimler Meslek Yüksekokulu Dergisi, 24 (2), 582-596. }\end{array}$} \\
\hline
\end{tabular}

\footnotetext{
${ }^{1}$ Bu çalışma, Tokat Gaziosmanpaşa Üniversitesi Lisansüstü Eğitim Enstitüsü tarafindan 04/08/2020 tarihinde kabul edilen yüksek lisans tezinden derlenmiştir.

* Prof. Dr., Tokat Gaziosmanpaşa Üniversitesi İktisadi ve İdari Bilimler Fakültesi, rustu.yayar@gop.edu.tr, ORCID: 0000-0001-6758-4715

** derya.arslan005@gmail.com, ORCID: 0000-0002-9755-9286
} 


\section{GİRIŞ}

Geçmiş zamanda insanlar yaşamlarını, küçük kasabalarda ve kendi ürettikleri ürünleri tüketerek dışa bağımlı olmadan aynı zamanda stresten de uzakta doğal yaşamda sürdürüyorlardı. Bu tip üretim ve yaşam biçiminde insanlar farkında olmadan sürdürülebilirliğin tabanda nasıl bir işleyiş göstereceğine model olup aynı zamanda sürdürülebilirliğe de katkı sağlıyorlardı.

Cittaslow ve SlowFood fikri; günümüzde küreselleşen aynılaşan kentler, yaşam biçimi ve yiyeceklere karş1 bir görüş olarak çıkmıştır. Bu fikir, sürdürülebilirlik konusunu ana tema olarak belirleyip kentleri, gıdaları, çevreyi ve ekonomik kalkınmayı sürdürülebilirlik ile harmanlayıp bir bütün halinde sistematik çalışmayı hedefler. Yerel anlamda sürdürülebilirlik, yerelde bulunan tüm dinamiklerin tümden harekete geçmesi ile yereldeki toplumun kalkınmada sürdürülebilirlik ilkesine uygun biçimde gelişimi olarak ifade eder (Pektaş, 2010: 7). Cittaslow, kentlerin ekonomik, kültürel ve çevresel sürdürülebilir olması fikrini uygulamada esas almış yenilikçi ve önem arz eden bir akımdır. İlk olarak İtalya'da ortaya çıkmış ve dünya çapına yayılım göstermiştir. 1999 yılından itibaren 'Cittaslow' kentler birliği ana teması olarak; kentlerin doğasına, esnafına, kültürüne, tarihine, yemeklerine ve yöresel ürünlerine saygı duyarak korumacı politikası ile sürdürülebilir olmakla birlikte sürdürülebilir yerel kalkınmayı hedefler. Tarihi dokuyu korumak, turizmi canlandırmak, çevreyi korumak, yerel ürünlerin tanıtımını sağlamak ve sosyoekonomik hayatın canlılığını sağlamak için Cittaslow akımı çok etkin bir modeldir. Küreselleşme olgusunun ortaya çıkardığı birbirine benzer sıradanlığa yatkın mekanlardan biri olmak istemeyen, çevrenin korunması ve geliştirilmesi, yerelde istihdamın artırılıp gelir sağlanması, yerel kimliği koruyarak dünyada yer almak isteyen kentlerin oluşturduğu Yavaş Şehir akımı; BM, OEDC VE AB'nin neredeyse tüm " sürdürülebilir kalkınma göstergelerini" 'içerip bunu uygulamada sağlayarak, hatta ve hatta birçok üstün taraflarının olmasını da dikkate aldığımızda, Cittaslow'un sürdürülebilir yerel kalkınma konusunda çok başarılı bir uygulama olduğu ifade edilebilir (Yalçın ve Yalın, 2013). Kaynakların daha sonraki nesillere ulaşabilmesi için sürdürülebilirlik, sürdürülebilir kalkınma ve yerel kalkınma ayrılmaz parçalar biçimindedir. Kamu kurumları ve yerelde özellikle belediyeler sürdürülebilirliğin önemli uygulayıcı mercilerdir.

Ulusal literatürde Cittaslow konusunda sınırlı sayıda çalışma bulunmaktadır. Karabağ vd.(2012)çalışmalarında; Yereldeki Cittaslow kentlerinde, Cittaslow üyeliğinin kültür turizmi açısından çok etkili olduğunu belirtmişlerdir. Cittaslow hareketinin yardımıyla kültürel varlıklarını koruyarak ve pazarlayarak bundan kalkınma açısından olumlu yönde yararlanabileceklerini dile getirmişlerdir. Cittaslow'un kültür turizmi, mekan markalaşmaya olumlu etkisi olduğunu belirtmişlerdir. Kültür turizminin yeni gelişim ve perspektiflere ihtiyacı olduğunu, Cittaslow ile kentlerin var olan potansiyel ile cazibe merkezi haline geleceğini, markalaşma ve tanımlama ile Cittaslow'un kentlere destek olacağını belirtmişledir. Cittaslow kriterleri ile yerel kimliğin ve kent görünürlüğünün arttığını dile getirmişlerdir. Yıldırım ve Karaahmet (2012)çalışmalarında; kent markalaşması açısından değerlendirmeler yaparak, Perşembe İlçesinin yavaş şehir sürecini yerel gazetelerden ve diğer yayınlardan incelemiştir. Kent markası oluşturma sürecine vurgu yapmışlardır. Perşembe ilçesinin Cittaslow unvanını aldıktan sonra, ilçe haberlerinin yerel basında ve ülke basınında daha çok yer aldığı, haber sayısının da iki kat arttığını tespit etmişlerdir. Yalçın ve Yalın (2013)çalışmalarında; Yerel kalkınma modeli olarak Cittaslow Hareketi ile ilgili bilgiler vermişlerdir. Türkiye'de ilk Cittaslow kenti olan Seferihisar Belediyesi ve diğer şehirlerin Cittaslow gelişimlerini inceleyerek, sürdürülebilir kalkınma açısından değerlendirmişlerdir. Cittaslow hareketinin BM, OECD ve AB' ne ait sürdürülebilir kalkınma hedeflerini sağladığını hatta daha çok üstün yönlerinin de olduğunu belirtmişlerdir. Cittaslow kentlerinde turizm ve kooperatifleşmenin arttığı, çevresel uygulamaları ile kentlere yeni bir sistem oluşturduğu, kentlere sürdürülebilirlik açısından bir yol haritası oluşturduğunu, sürdürülebilir yerel kalkınmanın başarılı bir uygulaması olduğunu belirtmişlerdir. Göker (2020)çalışmasında; Cittaslow ağına üye olan Halfeti kentinin çekiciliğini, hem turistlerin hem de yerel halkın bakışı ile değerlendirip analiz etmiştir. Bireylerin Cittaslow modeline karşı ilgi, eğilim, tercih ve özenme durumları analiz edilmiştir. Sonuç olarak kentin sosyal ve çevresel değerlerinin bozulmadığı, kültürel ve mimari yapısının ve geleneksel deneyimlerinin insanlar açısından çekici bir nitelikte olduğu görülmektedir. Kenti ziyaret eden turistlerin izlenim ve değerlendirmeleriyle Cittaslow kenti olan Halfeti'nin; yaşam kalitesi yüksek olan, kentin kimliğinin ve özünün korunduğu, yerel kalkınmayı savunan, tüm bunlarla birlikte teknolojiyi yerinde kullanan, marjinal, çekici ve yaşanılabilir bir kent modeli olduğunu belirtmiştir. Prezensa vd. (2015) çalışmalarında; Sürdürülebilir turizm yönetimi ve Cittaslow arasındaki ilişkiyi incelemişlerdir. Cittaslow üyesi olan kentlerde sürdürülebilir turizm ve yönetişimin olduğunu, Cittaslow'un sürdürülebilir turizm açısından bir teşvik olduğunu, uluslararası Sakin Şehirler ağında sertifikasyonun vardığı son noktanın sürdürülebilir kent ve sürdürülebilir kalkınma olduğu sonucuna varmışlardır. Cittaslow üyesi olmak isteyen kentlerin bu üyeliği 
sağlama sürecinde stratejik birçok konuda olumlu gelişimler kazandığı, kaynak israfının önlendiği kıt kaynak yönetiminde birçok olumlu etkisi olduğu gözlemlemişlerdir. Acuner (2014) çalışmasında; Çamlıhemşin ilçesinin Cittaslow üyeliğini değerlendirmek için karşılaştırmalı bir analiz yapmıştır. ABD - San Fransisco Kenti'nin Sebastopol kasabasını Çamlıhemşin ile benzerlik yönünden seçmiştir. Her iki kenti de seçerek gözlemci yorumu ve içerik analizi yapmıştır. Elde edilen bilgiler 1şığında Çamlıhemşin 'in Sakin Kent kriterlerinin \%51'ini sağladığı sonucuna uylaşmıştır. Çalışmalar esnasında Cittaslow üyeliğini yürütecek organizasyon yapısını da oluşturmuştur. Donat (2016)çalışmasında; Türkiye'de Sakin Kentlerdeki kamusal mekanları incelemiştir. Çalışmasında saha araştırması yapmıştır. 2015 yılında önce Türkiye'de Sakin Kent olan belediyeleri ziyaret edip, kentlerin kamusal mekanlarını gözlem metodu ile incelemiştir. Gözlemler sonucunda kentlerin Sakin Kent olduktan sonra yaşam kalitesinin yükseldiğini, kentlerde sürdürülebilirlik yaklaşımının ön plana çıtığını, kamusal mekanlarda olumlu etkisi olduğunu belirtmiştir. Belediyelerin Sakin Kent olma yönünde çalışmalarını daha da artırmalarını, yeni vizyonları ve bu üyelik ile belediyelerin eskisine göre marka imajı sahibi olacağını dile getirmiş̧ir. Çiçek (2017)çalışmasında; Marmara ve Ege Bölgesindeki Sakin Şehirlere yönelik bir anket çalışması uygulamıştır. Çalışmanın amacı yerel halkın turizme desteği ve Cittaslow akımına dair tutumları arasındaki ilişkiyi tespit edebilmektir. Toplamda 1143 kişiye anket çalışması uygulanmıştır. Sonuç olarak, Marmara ve Ege bölgelerindeki Cittaslow kentlerinde yaşayan halkın sakin şehir hareketi ve turizm desteği arasındaki ilişkiden haberdar olduğu ortaya çıkmıştır. Yaşam kalitesi ve turizm desteği arasında anlamlı bir ilişki bulunmuştur. Ayrıca turizmden faydalanan kişisel faydanın yüksek olduğu, Sakin Şehir ve turizm algılarının olumlu etkileşim içinde olduğu belirlenmiştir. (Miele, 2008)çalışmasında, Cittaslow'un hızlı yaşamın yayılmasına karşı nasıl sınırlar çizdiğini inceleyerek Cittaslow'un ne ürettiğini nasıl yaygınlaştı̆̆ını açıklamıştır. Orvieto ve San Vincenzo kentlerini kıyaslayarak teknoloji ve yavaşlık konusunu ele almıştır. Yerel koşulların, kentleri hız konusunda sınırlar çizerek yavaş üretim biçimiyle entegre olup o yönde üretim yapmaya teşvik ettiğini, Cittaslow prosedürlerinin yavaş ve hızlı arasındasınır çizdiğini tespit etmiştir.(Lowry ve Lee, 2011) çalışmalarında, Cittaslow ve yavaş turizm hakkında araştırmalar yapmışlardır. Yavaş turizmin nitel keşfedici olduğunu, yavaş yemek ve yavaş turizmin birbirine bağlı öğeler olduğunu belirtmişlerdir. Değişen trendler ve sistemler ile tüketimin de değiştiğini artan sayıda turistin yavaş şehir seyahatleri tercih ettiğini bununla birlikte yavaş turizmin de sosyal ve politik olarak dünyayı dolaştığını belirtmişlerdir.

$\mathrm{Bu}$ çalışmanın amacı; 'Cittaslow' yaklaşımı tanımlanarak sürdürülebilir yerel kalkınma stratejisi kapsamında incelenmesi ve Niksar İlçesi'nin 'Cittaslow' kriterleri ile değerlendirmesinin yapılarak üyelik potansiyelinin ortaya konulması hedeflenmiştir. Bu düşüncenin temelinde Niksar İlçesi ile bütünleşmiş tüm değerlerin korunarak tanıtımının yapılması, istihdam olanaklarının bu imaj ile artabileceğini ve kentte var olan potansiyelin Cittaslow hareketi ile olumlu yönde değerlenebileceği düşüncesi ön planda olmuştur. Diğer bir deyişle; bu çalışmada küreselleşme sürecinde aynılaşmış kentlerden biri olmak istemeyen kentlerin, sürdürülebilirliğini sağlamak ve ekonomik kalkınma hedefi ile ortaya çıkan Cittaslow Birliğinin önemini ortaya koyarak Niksar İlçesi'nin bu kriterlere uygunluğunu ekonomik, sosyokültürel ve çevresel durumunu ele alarak incelemektir. Bununla birlikte Sakin Şehir kriterleri değerlendirilmesi aşamasında Niksar Belediyesi arşivinden faydalanılmıştır. Çalışmada sürdürülebilir kalkınma, yerel kalkınma, Cittaslow ve SlowFood kavramları ve üyelik kriterleri açıklanmıştır. Cittaslow üyelik kriterleri açısından Niksar İlçesi'nin değerlendirilmesi yapılarak sahada uygulanan bir anket çalışmasına yer verilmiştir. İlgili anket 88 kişiye uygulanmıştır. Yapılan alan çalışmasında Niksar'ın Cittaslow olması durumunda çevresel, sosyal ve ekonomik açıdan değişimlerin ne yönde olabileceği tespit edilmeye çalışılmıştır.

\section{KAVRAMSAL ÇERÇEVE}

\subsection{Sürdürülebilirlik}

Sürdürülebilirlik, insanların daha iyi bir hayat standardına ulaşırken aynı zamanda kaynak kullanımında oluşan gerilimlere müdahale edilerek yeni sistemlerin oluşturulmasını ifade eder. Doğal kaynakların bilinçsiz kullanımı, küresel çapta iklimsel değişiklik, çevre kirliliğinin ciddi boyutlara ulaşması ve dünyada süregelen ekonomik krizler sürdürülebilirlik kavramını ortaya çıkarmıştır (Çahantimur ve Yıldı,, 2008:3). Sürdürülebilirlik ülkesel ve bölgesel olarak farklı kategorize edilebilir. Bölgesel sürdürülebilirlik kavramı özünde birden çok ülkeyi ilgilendiren fakat küresel düzeyde olmayan sorunları ifade eder. Ülkesel sürdürülebilirlik kavramı için, bölgesel yapı ayrımı ve yerel düzey arasında, ülkelerin ulusal çapta ekolojisi, çevresi, ekonomisi, sosyal yapısı gibi konularında, sürdürülebilirlik uygulama amacıyla makro düzeyde uzun vadede planlama yapılmalı ve eylem planı geliştirmelidir. Tüm bu faaliyetler için, belirlenmiş bazı uluslararası kurallara uygun olmak kaydı ile ulusal düzeyde yasal çerçevenin hazırlanması gerekir. Bu konu sade yöresellik 
ya da yerellikten ibaret değildir. Ahlaken tüm dünyayı ilgilendiren süreçlerin bütünüdür denilebilir (Akgül, 2010:135).

Sürdürülebilirlik yerel kalkınma bağlamında çevresel etkilerin değerlendirilmesini, kültür mirasının korunmasını, süreçlerin yönetiminde ve elde edilen çıktıda altyapı teknoloji ve aynı zamanda kurumların oryantasyonunun sağlanması kurallarının bütününü ifade etmektedir. Sürdürülebilir olmak belirli bir sınırdaki toplumu değil tüm dünyanın topyekûn sorunudur. Sınırların dışında küresel domino etkisi ile toplumun ve çevrenin fiziki, ekolojik, ekonomik ve sosyal faaliyetlerinin korunup daha da iyileştirilmesini hedef alır (Sezgin ve Ünüvar, 2011: 13).

Sürdürülebilirlik kavramı ilk olarak 1713'te Hans Carlvon Carlowitz tarafından kullanılmıştır. Carlowitz, yaşlı ağaçların kesimlerde tercih edilmesi ve kesildiği kadar da bir o kadar yeni ağaçlandırma sistemlerin kurulmas1 gerektiğini dile getirmiştir (Pisani, 2006: 85-86).

Hart(1999)' a göre sürdürülebilirliğin tanımı; çevresel, ekonomik, toplumsal açıdan evrensel küme şekli oluşturulmuş olup, şeklin içinde ortak bölge olan ekonomi yer almaktadır. Bu kavramlar bir bütün halinde lokomotif şeklinde birbirine bağlıdır. Herhangi bir sebep ile bir faktörde raydan çıkma söz konusu olduğunda diğer faktörler de aynı doğrultuda kelebek domino etkisi ile eş yönlü benzeşim gösterir. Ekonomide meydana gelen bir sorun toplumu tetikler ve dolayısıyla çevre de bundan olumsuz etkilenir. Çevrede meydana gelen negatif gelişim ya da çöküş toplumda hasarlara yol açar uzun ya da kısa vade fark etmeden ekonomik açıdan hasarlara sebep olur. Kavramsal bağl1lık ve şekildeki iç içe geçmiş gruplamalar birbirine bağlı etkileşim gösterir (Özmehmet, 2008:4).

\subsection{Sürdürülebilir Kalkınma}

1970 yılında Roma Kulübü tarafından çevre, büyüme ve kalkınma içerikli bir rapor hazırlanmıştır. Büyümenin sınırları ismindeki raporda çok hızlı bir şekilde artan nüfus ve doğal kaynakların da hızla artması ile Dünya'da 150 yıl içinde yaşanılamaz bir ortam oluşacağı, dünyanın yaşanılabilir özelliklerini hızla yitireceği dile getirilmiştir. 1971' de kurulan Greenpeace dünyadaki tüm yıkıcı etkilere karş1 ekosistemi savunmaya ve direnç göstermeye başlamıştır. 1972'de Stockholm'de BM İnsan ve Çevre Konferansı yapılmış ve bir bildirge hazırlanmıştır. Bu bildirgede sürdürülebilir kalkınma kavramının ilk adımları atılmış, zemin etüdü çalışmaları hazırlanmıştır. Artan bilinç düzeyi ve eko-kalkınma kavramı ile süregelen yıllarda 1987'de BM Dünya Çevre ve Kalkınma Komisyonunda 'Ortak Geleceğimiz' isimli rapor oluşturulmuştur. Raporda içerik olarak günümüzün gereksinimlerini karşılamak ve sürdürülebilir kalkınma için yol gösterici ilkeler yer almaktadır (Kula, 1998:150). Dünya Çevre ve Gelişme Komisyonu bu raporun çevre ve gelişim konusunda sürdürülebilir kalkınmayı; gelecek nesillerin ihtiyaçlarını gözeterek şimdiki neslin ihtiyaçlarını da ellerinden almadan yapılan çalışma biçimi olarak ifade etmiştir (World Commission on Environment and Development, 1987).

Kalkınma; kendi özel kimliğini ve yerleşimini koruyarak bir toplumda kültürel etkinlikleri, sosyalliği ve ekonomik çalışmaları güçlendirerek, bunların her bir alt sistemi ile etkileşim içinde olarak kontrol içindeki sistem olarak ifade edilebilir (Casanova, 2004: 26).

Sürdürülebilir kalkınma geleceği bugünle bütünleştiren kalkınma demektir. Birleşmiş Milletlere 1987 yılında sunulan bir raporda sürdürülebilir kalkınma, "bugünün ihtiyaçlarını, gelecek kuşakların da kendi ihtiyaçlarını karşılayabilme olanağından ödün vermeksizin karşılamak” olarak tanımlanmaktadır. Önceleri çevresel hassasiyet üzerine bina edilen bu kalkınma modeli, zamanla sosyal, kültürel ve siyasal alanlarda da gündeme gelmiştir (Zengin vd., 2014:98).

Sürdürülebilir kalkınmanın yeni bir kavram olarak gündemde tartışmalar konu olup uygulamada da kullanıldığı andan itibaren üç ana hattı ile ele alınmaktadır. Bu üç ana hat ekonomik, ekolojik ve çevresel faktör olarak tanımlanmıştır (Holmberg ve Sandbrook, 1992:23). Sosyal, çevresel ve ekonomik sürdürülebilirlik izahı şöyle yapılabilir. Sosyal anlamda sürdürülebilir olmak ticaretin adil yapılması ve adil ücret dağılımı ile çalışma koşullarının iyileştirilmesi, vatandaşların bilgileri ile becerileri ile yerel kültürün korunması, sağlıklı gıda için küresele karşı üretim ve tüketim belirlenmelerinin yapılmasıdır (Ursula, Sto ve Unni, 2010: 16). Çevresel anlamda Cittaslow bağlamlı sürdürülebilirlik gübre, hormon, antibiyotik kullanımı azaltan, hayvan refahı ve arazi kullanımı konusunda düzenlemeleri içerir (UrsuloSto ve Unni, 2010: 16). Ekonomik anlamda sürdürülebilirlik verimlilik, kalite planlı üretim ile karlılık öngörülmektedir (Ursulo Sto ve Unni, 2010: 16).

\subsection{Yerel Kalkınma}

Yerel kalkınma son zamanlarda çok sık kullanılan bir kavramdır. Ulusal kalkınmanın alt basamağını bölgesel kalkınma oluştururken, bölgesel kalkınmanın alt basamağını da yerel kalkınma oluşturmalıdır. Yerel 
kalkınma kavramı bölgesel çapta firsatların ve avantajların yerelde bulunan aktörler tarafindan, bölgede bulunan doğal kaynakların kültürel değerlerin, tüm beşeri kaynakların verimli bir biçimde kullanılmasını ifade eder (Çarkçı, 2008: 59). Yerel kalkınma anlayışının iyi uygulanabilmesi için BM tarafından gündeme getirilen "Yerel Gündem 21" ile yerel kalkınmanın diğer vazgeçilmezleri olan katılım ve yetkinin yerele devri gerekmektedir (Zengin vd., 2014:104).

Geleneksel kalkınma ve yerel kalkınma işleyiş açısından farklılıklar gösterir. Yerelden merkeze ya da merkezden yerele dikey ya da yeri geldiğinde yatay uygulamalar içerir. Nerede nasıl ve hangi durumda yerel politikalar uygulanacak, yerel birimlerden nasıl talepler gelecek ve bu isteklere merkezi yönetim nasıl uygulanabilirlik sağlayacak tüm bu sistem yönetişimleri belirlenip, uygulamalar yatay ya da dikey koordinasyonlar ile sağlanır (Lım,2003:2). Yerel kalkınma; kırsaldan yerele, yerelden bölgesele, bölgeselden ulusala doğru ivme gösterir. "Ulusal kalkınmanın, insan vücudundaki kan dolaşım sistemi olarak değerlendirmesi durumunda, bölgesel kalkınma da ana damarları, yerel kalkınma ise kılcal damarları temsil edecektir. Sistemin sağlıklı işlemesi ise, ancak sistemi oluşturan her parçanın sağlıklı işlemesiyle mümkündür..." (Kaya, 2007: 19).

Yerel ekonomik kalkınma modelinde; yerelden minimalist salt o bölgeyi ilgilendiren çalışmalar, kamu ve özel sektörün yatayda analizleri ile dikey bir biçimde sorunsalın dikeye ulaşmasıdır. Alan çalışmaları daha çok yerel hareketlere ve çevresel faktörlere dayanır. Yöre potansiyeli her ne ise ayrıntısıyla tespit edilerek ekonomik yerel kalkınma aktiviteleri için koşullar belirlenip uygulamalar için merkezden destek alınır (Rodriguez-Pose, 2001:9).

\subsection{SlowFood(Yavaş Yemek)}

SlowFood akımı 1986'da İtalya'nın Langhe bölgesinde gastronomi konusunda önde gelen isimlerden biri olan Carlo Petrini tarafindan başlatılmıştır. Bu akımın oluşmasının ana nedeni Roma Piazza'dafastfood modasının başlamasına neden olan Mcdonald's açılması konusuna kuvvetli bir tepkidir (Yurtseven, 2007:3).İtalya' da yerel yemek kültürlerinin hızlı yaşamın yükselişine karşı ortadan kalkmasını önlemek amacı ile 1989 y1lından itibaren görev yapan bir kuruluştur.

SlowFood iyi olan, temiz ve adillik felsefesi ile hareket edip benimsemektedir. İyi ve adil gidadan kasıt; sağlıklı olmasıyla birlikte kaliteli ve lezzetli olan gıdadır.Bu gıdanın üretiminde çevreye zarar vermeyen üretimler ile tüketicilerin bütçesine uygun fiyatlar ile işleten şeffaf yöntemleri ifade etmektedir (www.slowfood.com, 2019).

SlowFood, iyiye odaklanan yaşam tarzını belirleyen, çevre ve toplum sağlığını önemseyen koruma bilinci altında yaşam tarzındaki değişikliklerin tanıtılmasını ifade eder. Yavaş yemek; sağlam bir vücut için bölgesel gıdaların tüketiminin, tanıtımının sağlanması çalışmalarının özünü ifade etmektedir (Fell ve Lukianova, 2015: 60).

SlowFood akımı dünya çapında 160'dan fazla ülkenin de desteği ile yemek ve çevreye dikkatleri çekerek sorumluluklarını yerine getiren kuruluştur. Uzman ve akademisyenlerin de bulunduğu yaklaşık 100.000 SlowFood üyesi bulunmaktadır. Parasal bir çıkarı olmayan, kar amacı gütmeyen bir akımdır. İlk olarak 1989'da hızlı yemek (fastfood) ve sanayi tipi yemek biçimine karşı olarak, insanların yediklerinin farkında olmasına dikkatleri çekmiştir. Yemek tarihinin, tatların, yerel yemek kültürlerinin yok olmasına karşı mücadele vererek küresel çapta çalışmaları olan kuruluştur. Türkiye de ilk SlowFood köyü İzmir' in Çeşme İlçesinin Germiyan kasabasıdır. 15 Mayıs 2016'da süreç tamamlanmıştır. Germiyan'da her Ekim ayında düzenlenen festivalde yöresel ürünlerin tanıtımı yapılmaktadır. Germiyan'da yaşayan köy halkının atalarından emanet doğal ve yerel tohumların ekilmesiyle elde edilen mahsullerden yapılır. Yeni butik oteller ve yöresel restoranlar mevcuttur. SlowFood festivali döneminde yüksek oranda turist gelmesi bölgeye çok fazla ekonomik getiri sağlamaktadır. Aydın, Balıkesir, Çanakkale, İzmir, Muğla, Samsun ve İstanbul gibi çok sayıda şehrimizde yerel topluluklar ve SlowFood girişimleri yer almaktadır (Çelikhisar, Karşıyaka gazetesi, 2019). SlowFood adına dünyada birçok etkinlik, faaliyet yapılmaktadır. Bunlardan bazıları; Sefertası Akımı, TerraMadre (Toprak Ana, Mother Earth) günü, Yiyeceklerin ve Lezzetlerin Tattırımı Faaliyetleri, Nuh'un Ambarı (Ark of Taste) Projesi, SlowFoodYouth Network (SlowFood Gençlik Gıda Hareketi). SlowFood köyü ya da kenti olmak bölgeye tersine göç ve ekonomik katkı sağlar.

SlowFood misyonu ve vizyonu için temel eylem; üretilen gıdaların kaliteli ve lezzetli olması, üretim şeklinin sürdürülebilir uygulamalara dayalı olması en önemli konular arasında olup, üretici-tüketici arasında dengeleri koruyan birbirine bağdaşmış üç ilkeden meydana gelmektedir; "adil, temiz ve iyi” (Walter, 2009:1).

Toplumun yerel değerlere odaklanmasını sağlayan, kültürel farklılıkların aslında özel bir durum olduğunu, yerelliği ön plana çıkartan yavaş akımı uygulamaları benimsenmiştir (Öztürk, 2012: 62). 


\subsection{Cittaslow (Sakin kent)}

Küreselleşme karşıtı topluluklar hareketlerini yerel çapta yapmalarına karşın bu eylemlerin yankısı uluslararası çapta ses getirmektedir (Juris, 2005:195). Cittaslow hareketi bu yaklaşımlardan birisidir. İnsanlar yavaşlık özentisi içine bazı akımlar ile giriş yapmıştır. Toplumların olması gerektiği gibi özgünlüguünü koruyarak sürdürülebilir olması bu şekilde mümkün kılınabilir. 1986'da Roma'da FastFood'a karşı büyük bir başkaldırış olan SlowFood akımı bu yaklaşımlardan biridir. Böylece yavaş hareketi küreselleşen dünyaya ve hızlı yaşama karşı toplumsal bir eylem olarak dünyada yer almıştır. Yavaş hareketi, bütün küreselleşmeye karş1 olan hareketlerin de tanımlaması gibi yerelliğe karşı küreselleşmeyi bir tehdit olarak görmektedir (Acar, 2016: 98).

Cittaslow akımı, kent nüfusu 1.500 ile 50.000 senkronunda seyreden daha küçük kentlerin ya da büyük çaplı kasabaların dahil olabileceği uluslararası çapta işlev gören bir ağdır. Cittaslow Hareketi en temel düşüncesiyle, yerel ve yöresel çevrenin ve o yerel çevreye ait yerel lezzetlerin kalitesinin yükseltilmesi (veya var olanın korunması ya da coğrafi işaret olarak tespit edilmesi) bu şekilde o yerleşimde yaşayanlar ve buraya ziyarete gelenler için "kaliteli yaşam" koşulunun standartının sağlanması olarak ifade edilmektedir (Erten, 2009:106).SlowFood akımıyla birlikte İtalya'nın küçük bir şehri olan Chianti'de hayat bulan Cittaslow akımı, "kentsel üretim, çevresel değerlerin, kültürel ve yöresel ürünlerin korunması ile birlikte sürdürülebilirliğin sağlanması" olarak açıklanan amaçları olan bir harekettir (Kadıŏlu, 2009: 72-76).

1999 yılında Cittaslow akımı Grevein Chianti kentinin belediye başkanı PaoloSaturnini'nin öngörüleri çerçevesinde ortaya çıkmıştır. 1986 'da ortaya çıkan yavaş yemek akımı, Sakin Kent fikrinin oluşmasına da örnek olmuştur. SlowFood akımının yerel üretimi ve ürünleri destekleyen anlayışı Sakinlik akımının kentsel perspektifte uygulanmasına ilham kaynağı olmuştur (Radstorm, 2011:93-96). Cittaslow İtalyanca'da kent İngilizce'de yavaş sözcükleri bir araya getirilerek oluşturulan uluslararası akımdır. 2001 yılında Uluslararası Sakin Kentler Tüzügünde de bu isim ile yer almaktadır (Servon ve Pink, 2015: 338).

Slow hareketi kendi içinde bir kurumsal hareket değildir. İdari bir yönetimi, önderi ve yönetim ofisi yoktur. Bu planlamacılar yerel kimlik ve bu kimliğin nasıl sürdürüleceğine odaklanmışlardır. Bölgesel planlamalar, bölgesel kalkınma ajansları her bir kentsel alanın özelliklerini değerlerini tespit edip bu konuda sürdürülebilirlik planları uygulamaktadırlar (Honore, 2008:18).

Sakin kentlere üye olabilmek için kentlerin öncelikle birtakım ön hazırlıklar yapması gerekmektedir. Başvuru öncesinde kabul görülebilirlik konusunda başarılı olabilmek adına kentlerin Cittaslow kriterlerini gözden geçirip hangi konuda nasıl bir eksiklik söz konusu olduğu tespit edilmelidir. Gözlem sonucunda öncelikle değerlendirmeler ile niyet mektubu ile Cittaslow koordine merkezi ile iletişime geçilir. Sonraki aşamada uluslararası komite ve belediye arasında iletişim ve yapılması istenilenler çerçevesinde sistemli biçimde üyelik adına çalışmalar yürütülmeye başlar. Cittaslowkriterleri toplam 7 ana başlık altında 72 adettir. Üye olmak isteyen belediyelerin ön çalışmalar ile 72 adet kriterin toplamda en az \%50 sini sağlaması gerekmektedir.

Cittaslow kriterlerinin ana başlıkları; Çevre politikaları, Altyapı politikaları, Kentsel yaşam kalitesi politikaları, Tarımsal turistik esnaf ve sanatkârlara dair politikalar, Misafirperverlik, farkındalık ve eğitim için planlar, Sosyal uyum, Ortaklıklar olarak 7 başlıktan oluşmaktadır (www.cittaslowturkiye.org).

Cittaslow ağının dünya çapında dağılım göstermesi ile bu akıma Türkiye'de de 2020 itibari ile 18 adet üye kent bulunmaktadır. Yavaş Şehir ağına üye olan bu kentlerimiz; Akyaka, Eğirdir, Gerze, Gökçeada, Göynük, Halfeti, Perşembe, Şavşat, Seferihisar, Taraklı, Uzundere, Vize, Yalvaç, Yenipazar, Mudurnu, Köyceğiz, Ahlat ve son olarak Ankara(Güdül) Yavaş Şehirler ağına katılmıştır (www.cittaslowturkiye.org). Cittaslow ağına 2009'da katılan ilk kentimiz İzmir/Seferihisar'dır. Bu sebeple Türkiye Cittaslow Koordidatörlüğü merkezi Seferihisar'dır. Günümüzde Dünya çapında 30 ülkede, 264 şehirde Cittaslow üyeliği bulunmaktadır. Bu kentlerin 20 adet dünya genelinde ağı bulunmaktadır. Merkezi PalazzoDei Sette, Orvieto(İtalya)'dır (www.cittaslow.org).

Yavaş Şehir ağı kalkınma ve sürdürülebilirlik kavramlarının bir ağ halinde dünyadaki çeşitliliğinin ve özgünlüğünün korunmasını hedef alır. Sürdürülebilir kalınmada ulusların alt birimleri şeklinde nitelendirilen bölge kavramı yerine, kendi çehresinde kendi standartlarına ve kendine özgü potansiyeline göre yetebilirlik ‘'yerel" sözcügünü gündeme getirmiştir (Eraydın, 2004:126). Cittaslow dünya çapında güçlü dinamiklerin eleştirel konusu halini almıştır. Cittaslow kalkınma modelinin modernleşen dünyada nasıl yer edebileceğini, yeni bir dünya sisteminde yöresellik, yerellik ve kalkınma üçlüsünün boyutları değerlendirilerek çalışmalara konu olmuştur. Günümüzde ihtiyaçlarımızı karşılamaya çalışırken, insan olmanın gerektirdiği özellikleri ve gelecek nesiller için duyarlı olarak yarınki ihtiyacımızı farklılaştırarak belki de isteklerimizden feragat ederiz (Hahnel, 2004: 19). 


\subsection{SlowTourism (Yavaş turizm)}

2020 y1lında ortaya çıkan Covid-19 virüsü ve dünyada pandemi ile birlikte artık alış1lagelmiş yaşam tarzlarımız tamamen değişime uğradı. Ekonomik, sosyal ve kültürel tüm faaliyetlerde artık alternatif olan yerel ve yerinde yapılabilecek aktiviteler tercih edilmeye başland1. Slow Turizm bu süreçte yerel ve yerinde faaliyetlerin bütününü içerdiğinden dolayı son dönemlerde daha popüler, güvenli bulunan bir turizm türüdür.

Turizmin temel taşlarından olan coğrafi ve ekolojik güzellik, beşeri özellikler, fiziki faktörler, tarihi yapılar ve söz konusu tarihi, ulaşım ve konaklama imkanları hep bir arada harmanlandığında temel faktörleri oluşturur. Özellikle son yıllarda bir bina ya da tesisin sunduğu tatil imkanından faydalanmayı red edip daha çok yöreselliğin farkına varmayı, yerel tatları keşfetmeyi, doğal ve tarihi güzellikleri görmeyi arzulamaktadır. Bu tip isteklerin ön planda olması 'Yavaş Şehirler' ve 'Yavaş Turizm' kavramlarını daha çok ön plana çıkartmaktadır (Ünal, 2016: 21-23). Lowry ve Lee (2011) yaptıkları araştırma neticesinde yavaş turizmi kategorize ederken Şehir turizmi ve kırsal turizm kategorisinin her ikisinde de değerlendirilebileceğine kanaat getirmişlerdir. Büyük kentlerdeki sürdürülebilir kalkınma için yapılan planlamalara karşın Yavaş Şehir hareketleri Sürdürülebilir Tüketim ve Üretim (STÜ) fikri ile yeni yapılanmalar oluşturmuştur. Kendi bünyesinde barındırdığı yaşam ortamı, doğal yapısı, ekolojisi, tarihi değerleri ile turizm açısından kaliteli bir ortam oluşturur. Cittaslow modellemesinin eko turizm ve agro turizm açısından yerel düzeyde kalkınmaya imkan sağladığı görülmektedir (Hekimci, 2014:2).

\subsection{Cittaslow Kriterleri ile Yerel Kalkınmaílişsisi}

Yerel kalkınma anlamında Yavaş Şehirler yepyeni bir kavramsal model oluşturmuştur. Bu modelin riskleri ve fırsatları değerlendirildiğinde en çok dikkat çeken kısmı fırsatlarının ön plana çıkmasıdır. Yavaş Şehir ağı insan yaşamının gelişen ve gözlemlenebilen olumsuz faktörlerinin azaltılmasını, fiziki değerlerinin korunmasını ve yerel çapta tüm değerlerin gelecek nesillere aktarılmasını sürdürülebilirlik çerçevesinde sağlar. Çevreye zarar vermeyen yenilenebilir enerji kaynaklarının kullanımına destek ve öncülük sağlar. Kalkınma ve sürdürülebilirlik kavramlarının bir ağ halinde dünyadaki çeşitliliğinin ve özgünlüğünün korunmasını hedef alır. Sürdürülebilir kalınmada ulusların alt birimleri şeklinde nitelendirilen bölge kavramı yerine, kendi çehresinde kendi standartlarına ve kendine özgü potansiyeline göre yetebilirlik 'yerel" sözcügünü gündeme getirmiştir ( Eraydın, 2004: 126).

Genel olarak küçük şehirlerin sosyal olanakları, iş ve istihdam olanağı kısıtlıdır. Tam da bu sebepten dolayı genç nüfus çoğu zaman büyük kentlere göç etmektedir. Ekonomik potansiyeli olmayan kentler zamanla durağanlaşıp bu durağanlıktan kurtulamayıp ölmektedir. Bu tür kentler kendi kimliğine sahip çıkarak ivme kazanabilir Çöküş altındaki bu kentler için Cittaslow yeni olanaklar sağlar. Kent doğasına sahip çıkmak, esnafını tanıtım ve turizm ile canlandırmak, tarihine, yemeklerine, üretilen yerel ürünlerine sahip çıkılarak bu ağ sistemi ile sosyal ve ekonomik hayatın canlanması kentlerin kendi ayakları üstünde durması için iyi bir modelleme olmaktadır. Sakin Şehir akımı kadın girişimciliğinin artmasında etkili olup, yapılan bu çalışmalar diğer kadınlara da ilham vermektedir. Kadınlara verilen girişimcilik kursları ile bilgi desteklenip tüm bu çalışmalar sonucu ortaya kooperatifler çıkmıştır (Sungur, 2013: 647). Kentlerin ekonomik olarak sürdürülebilir olmasının en önemli hedeflerinden bir tanesi de Yavaş Şehirdeki kamu hizmetlerinin etkin, özgün ve verimli olarak sunumunun yapılmasıdır (Yazar, 2006: 72). Sakin Şehir akımı planlama hareketinden ibaret değildir. $\mathrm{Bu}$ akım kentlerin gelişmesi ve küreselleşmenin etkisi altında kalarak özgün ruhlarını kaybetmeden aşama kat etmesidir ( Doğrusoy ve Dalgakıran, 2011: 132). Farkındalık ile Sakin Şehir çalışmalarının genel geçer bir akım değil, kentlere yenilikler oluşturan devrim niteliği taşıyan akımdır (Hatipoğlu,2015: 23).

\section{CITTASLOW KRITERLERİ AÇISINDAN NIKSAR ILÇESI'NİN DEĞERLENDİRILMESİ}

Niksar 1861 yılında kurulmuş, 350 m rakımda, Tokat iline bağl1, Orta Karadaniz'de bulunan tarihi ve ekolojik dokuya sahip şirin bir ilçedir. Tarihi değerlerin, coğrafi ve tabiat dokusunun bir bütün olduğu Niksar; Hitit, Pers, Pontus, Roma, Bizans, Danişmend, Selçuklu, Beylikler Döneminde ve Osmanlı zamanında her dönem için detaylı bir şekilde cazibe merkezi olmuştur (Şenol, 2013). 2019 Yılı verilerine göre ilçe nüfusu 65.308'dir. Şehir merkezi nüfusu 38.753'tür.İlçede ekonomik döngü genel olarak tarım, hayvancılık ve orman ürünlerinden oluşan ürünler ile sağlanır. Niksar'da bazı tarihi ve turistik mekanların olması bölgenin ekonomik kalkınmasına destek verme potansiyeline sahiptir. Köklü geçmişi Roma dönemine kadar dayanan bir kentte turizm ekonomisi konusunda sürdürülebilir düzeyde kalkınma sağlamak diğer örnekler gibi tipik bir biçimde mümkündür. Kentin sahip olduğu hali hazırda değerleri ön plana çıkartmak Cittaslow modellemesine uygun statüde bir kent olduğu öngörüsü ile kentin Cittaslow açısından ön değerlendirmesi yapılmıştır.

Niksar, Cittaslow için niyet mektubu göndermiş bir kent olarak Yavaş Şehir ağına dahil olma niyetinde olduğunu belirtmiştir. Bu çalışmanın temel hedefi sürdürülebilir yerel düzeyde kalkınma için Cittaslow 
modelleşmesinin Niksar İlçesi açısından yüksek oranda katkısı olacağı düşüncesi ile Niksar'ın üyelik potansiyeli durumunu tespit etmek için, Cittaslow'a ait 72 adet kriterin her biri incelenerek, Niksar'ın hangi oranda kriterleri sağladığına dair bir potansiyel sonuca ulaşmaktır. Cittaslow'un 72 kriterleri teması genel çerçevesi ile doğayı koruyan, sürdürülebilir ekonomi politikaları içeren, kentlerin ekonomik ve mali yapısında değişiklik oluşturan hedeflemeler içermektedir. Cittaslow kriterleri genel olarak 7 ana başlık altında toplanır. Bu başlıklar;

1) Çevreye dair politikalar

2) Altyapıya dair politikalar

3) Kentsel ortam ve yaşam kalitesi ile ilgili politikalar

4) Tanıtım, turizm, esnaflara ve sanatkarlara yönelik politikalar

5) Konukseverlik(misafirperverlik) ve farkındalık eğitimi için planlar

6) Sosyal uyumlar

7) Ortaklık politikaları(www.cittaslow.org).

7 ana başlık altında bulunan 72 alt başlığa ait kriter değerlendirmeleri ayrı ayrı yapılmıştır. Bu değerlemeler Niksar Belediyesi arşivleri, plan projeleri ve gözlemler yolu ile yapılmıştır. Yetkili kurumlar ile birebir görüşmeler yapılıp, gerekli plan proje incelemeleri yapıldıktan sonra her biri ayrı başlık altında değerlendirilmiştir.

Alan yazın taramaları yapılarak, ilgili tüm kurumlar ile görüşmeler sağlanarak, Cittaslow kriterleri ışığında uyumluluk analizi değerlendirilmiştir. $\mathrm{Bu}$ değerlendirmeye göre; Niksar adına yapılan 72 adet kriter değerlendirmesinde 7 makro başlığın alt başlıklarından en az biri yada birden fazlasında kriter değerlendirmesi kapsamında başarılı bulunmuştur. Niksar ilçe nüfusu 50.000'in altında olduğu için önemli aşamalardan birini geçmiştir. Kriterlerin tanımlanması ve uygunluk tespiti yapılmıştır. Değerlendirme sonucuna göre 72 alt maddeden 22 adedinde konu ile ilgili çalışma bulunmayıp, 50 adedinde ise plan, proje ve uygulanan çalışmalar mevcut olduğu gözlemlenmiştir. Potansiyel olarak Cittaslow kriterleri açısından Niksar'ın genel çerçevesi ile pozitif yönde ve hali hazırda uygulamaları olduğu gözlemlenmiştir. Cittaslow komitesi başvuru dosyasını incelediğinde $\% 50$ oranında olumlu kriter aramaktadır. Bu çalışma kapsamında yapılan değerlendirmede Niksar'ın hali hazırda kriterlerin \% 69'unu karşıladığı tespit edilmiştir. Aynı zamanda üyelik süreci konusunda potansiyel ön değerlendirmesi yapıldığı esnada hâlihazırda sağlanan kriterler ile çeşitli süreçlerde uzun vadede süregelecek projelerde üyelik dosyasında bulunacağından dolayı süreçte yüzdelik oranı değişken olacaktır. Tüm bu detaylar içerisinde yapılan ön değerlendirmede Niksar İlçesi genel çerçevesi ile pozitif yönde potansiyeli barındırmaktadır.

\section{NIKSAR'IN SAKINN ŞEHIR OLMASINI TESPIT ETMEYE YÖNELİK ALAN ARAŞTIRMASI}

$\mathrm{Bu}$ bölümde Niksar ilçesi kamu kurumlarında istihdam edilen bireylerin sakin şehir konusundaki düşünceleri araştırılmıştır. Bu amaçla Niksar Sakin Şehir farkındalığını belirlemek ve Niksar'ın Sakin Şehir olması durumu kentin ekonomik, sosyal ve çevresel açıdan nasıl etkileyeceğini tespit etmektir. Yapılan bu çalışma Cittaslow kenti olmak için niyet mektubu gönderen Niksar İlçesi yöneticileri için yol gösterici olabilecektir. Bu bölümde literatürden yararlanarak doğrulayıcı faktör analizi yapılmıştır. Faktör analizinde yer verilen ifadeler tamamıyla sakin şehir kriterleriyle ilgilidir. B analizle bölgede ikamet eden halkın sakin şehir kriterleri açısından tutumunu tespit etmek amaçlanmıştır.

\subsection{Veri ve Yöntem}

Araştırmada hem daha önce yapılmış çalışmalardan hem de anket yoluyla elde edilen verilerden yararlanılmıştır. Hazırlanan anket formunda 52 adet soruya yer verilmiştir. Anket formunun oluşturulmasında literatür taraması yapılarak; Çakıcı, Yenipınar ve Benli (2014),Kuvan ve Akan (2005) ve Özgen (2012)'in konu ile ilgili geliştirdikleri ölçek ile Özmen, Birsen ve Birsen (2017) tarafından geliştirilen ölçekten faydalanılmıştır. Anketin ilk 7 sorusu demografik ve sosyal özellikler ile ilgili sorulardır sonrasındaki tüm sorular katılımcıların Niksar ve Cittaslow bağına dair cevapladıkları sorulardan oluşmaktadır. Ankette öncelikle Sakin Şehir algısının tespitine dair sorulara yer verilmiştir. Sonrasında yerel kalkınma ve sürdürülebilir kalkınma ile Sakin Şehir bağına yönelik sorular yer almaktadır. Daha sonra katılımcıların Sakin Şehre dair çevresel, ekonomik ve sosyal anlamda cevapladıkları sorulardan oluşmaktadır. Demografik ve sosyal özellikli sorular hariç diğer sorular; sırasıyla hiç katılmıyorum, katılmıyorum, kararsızım, katılıyorum ve tamamen katılıyorum şeklinde beşli likert ölçeğine uygun olarak hazırlanmıştır.

Bu çalışmanın ana evreni Niksar İlçesinde ikamet eden kamuda görevli çok farklı kategorilerde unvanlara sahip 18 yaş üstü bilirkişi ve üst düzey yöneticiyi kapsamaktadır. İlçedeki Kamu kurum ve kuruluşundaki üst düzey yöneticiler ve İlçedeki bilirkişi sayısı yaklaşık 2500 kişi civarında olup bu sayı için evren $\alpha=+0,05 /-$

Selçuk Üniversitesi Sosyal Bilimler Meslek Yüksekokulu Dergisi, Yıl: 2021 Cilt: 24 Sayı:2 
0,05 örnekleme hatası, $\mathrm{p}=0,5 \mathrm{q}=0,5$ için örneklem sayısı 75 kişidir. Yapılan anketlerden 88 kişiye ulaşılmıştır ve anketlerin hepsi değerlendirilmeye alınmıştır.

Anket uygulaması sonucu tüm veriler sınıflandırılmış ve veri girişine uygun biçimde hazırlanmıştır. Son olarak da SPSS programinda faktör analizi, frekans analizi, KMO ve Bartlett's testi, grup istatistikleri, güvenirlilik analizi, anova ve $t$ testi uygulanmıştır.

\subsection{Araştırma Bulguları}

İlk olarak katılımcılara ilişkin demografik özellikler analiz edilmiştir. İkinci olarak katılımcıların Niksar, Sakin Şehir ve kalkınmaya yönelik düşüncelerine yer verilmiştir. Üçüncü olarak sakin şehir hareketi algısı ve sakin şehir algısı ve destekleme faktör analizi yapılmıştır. Son olarak, katılımcıların çeşitli özellik ve düşüncelerine göre tek yönlü varyans ve t testi analizi uygulanmıştır. Katılımcıların demografik özelliklerine ilişkin analiz sonuçları Tablo 1'de verilmiştir.

Tablo incelendiğinde katılımcıların\%63,6'sı erkek, \%36,4's1 kadınlardan oluşmaktadır. Katılımcıların yaş dağılımına göre; \%14,8'i (13 kişi) 18-30 yaş arasında, \%26,1'i (23 kişi) 31-40 yaş arasında, \%33'ü (29 kişi) 41-50 yaş arasında, \%19,3’ü (17 kişi) 51-60 yaş arasında, \%6,8’i (6 kişi) 61 yaş üstündedir.

Tablo 1. Katılımcıların Demografik Özellikleri

\begin{tabular}{|c|c|c|c|c|c|c|c|}
\hline & & $\mathrm{N}$ & $\%$ & & & $\mathrm{n}$ & $\%$ \\
\hline \multirow[t]{2}{*}{ Cinsiyet } & Erkek & 56 & 63,6 & \multirow[t]{5}{*}{ Yaş } & $18-30$ & 13 & 14,8 \\
\hline & Kadın & 32 & 36,4 & & $31-40$ & 23 & 26,1 \\
\hline \multirow[t]{5}{*}{ Eğitim } & Ortaokul & 2 & 2,3 & & $41-50$ & 29 & 33 \\
\hline & Lise & 18 & 20,5 & & $51-60$ & 17 & 19,3 \\
\hline & Ön Lisans & 7 & 8 & & $61+$ & 6 & 6,8 \\
\hline & Lisans & 52 & 59,1 & \multirow{7}{*}{$\begin{array}{l}\text { Niksar'da } \\
\text { İkamet } \\
\text { Süresi }\end{array}$} & $1-5 Y_{11}$ & 5 & 5,7 \\
\hline & Lisans Üstü & 9 & 10,2 & & 6-10 Y1l & 11 & 12,5 \\
\hline \multirow[t]{5}{*}{ Gelir Seviyesi } & $2500 \mathrm{TL}$ ve alt 1 & 6 & 6,8 & & 11-15 Yil & 6 & 6,8 \\
\hline & 2500 TL-5000 TL & 28 & 31,8 & & $16-20 \mathrm{Y}_{11}$ & 11 & 12,5 \\
\hline & 5000 TL-7500 TL & 33 & 37,5 & & 21 Yıl ve Üstü & 55 & 62,5 \\
\hline & 7500 TL-10000 TL & 6 & 6,8 & & & & \\
\hline & 10000 TL ve üzeri & 15 & 17 & & & & \\
\hline
\end{tabular}

Katılımcıların eğitim durumlarına göre; \%2,3’ü (2 kişi) ortaokul mezunu, \%20,5'i (18 kişi) lise mezunu, \%8'i (7 kişi)ön lisans mezunu, \%59,1'i (52 kişi) lisans mezunu, \%10,2’i (9 kişi) lisansüstü mezunudur. Katılımcıların Niksar'da ikamet sürelerine göre; \%62,5’i (55 kişi) büyük bir oranla 21 yıl ve üstünde Niksar'da yaşamaktadır, Bunu takiben \%12,5'i (11 kişi) de 16-20 yıl arası Niksar'da ikamet etmektedir. Katılımcıların gelir seviyelerine göre; \%17'sinin (15 kişi) gelir seviyesi 10.000 ve üstüdür.5000 ve altı gelir seviyesine sahip olanların oranı \%39'dur (34 kişi).

Katılımcıların Niksar, sakin şehir ve kalkınmaya yönelik görüş ve düşüncelerine ilişkin veriler Tablo 2‘de verilmiştir.

Tablo 2 incelendiğinde, 88 katılımcıdan 72'si Niksar dışında başka bir yerde yaşamıştır. Katılımcıların \%51'i Niksar dışında başka bir yerde yaşamayı düşünürken, Sakin Şehir kavramını ilk kez bu ankette duyan katılımciların oran $1 \% 42$ 'dir.

Sakin Şehir kavramını ilk defa duyulan kaynaklar incelendiğinde; anket \%36,4 oran ile ilk sırada yer alırken bunu sırasıyla 23,9 oran ile internet, $\% 17$ oran ile sosyal çevre ve $\% 12,5$ oran ile televizyon takip etmektedir. Sakin Şehir kavramını anket dışında diğer kaynaklardan öğrenme oranı yüksek olduğu için konuyla ilgili katılımcıların düzeylerinin yüksek olduğu söylenebilir. Katılımcıların \%74'ü Niksar'ın Sakin Şehir olması için öncelikle halkın bilgisine başvurulması gerektiğini düşünmektedir. Bununla birlikte Niksar'ın Sakin Şehir unvanına sahip olmasını isteyenlerin oranı \%95,5 olup çok yüksek düzeydedir. 
Tablo 2.Katılımcıların Niksar, Sakin Şehir ve Kalkınmaya Yönelik Bilgileri

\begin{tabular}{|c|c|c|c|}
\hline & & $\mathrm{n}$ & $\%$ \\
\hline \multirow{2}{*}{ Niksar dişında başka bir yerde yaşama } & Evet & 72 & 81,8 \\
\hline & Hayır & 16 & 18,2 \\
\hline \multirow{2}{*}{ Gelecekte Niksar dışında başka bir yerde yaşamayı düşünme } & Evet & 45 & 51,1 \\
\hline & Hayır & 43 & 48,9 \\
\hline \multirow{2}{*}{ Cittaslow kavramını ilk kez bu ankette duyma } & Evet & 37 & 42 \\
\hline & Hayır & 51 & 58 \\
\hline \multirow{6}{*}{ Sakin Şehir kavramını ilk defa duyulan kaynak } & İnternet & 21 & 23,9 \\
\hline & Televizyon & 11 & 12,5 \\
\hline & Anket & 32 & 36,4 \\
\hline & Ulusal Basin & 5 & 5,7 \\
\hline & Bilgi Toplantıs1 & 4 & 4,5 \\
\hline & Sosyal Çevre & 15 & 17 \\
\hline \multirow{2}{*}{ Sakin Şehir olmak için önce halkın bilgisine başvurulma } & Evet & 65 & 73,9 \\
\hline & Hayır & 23 & 26,1 \\
\hline \multirow{4}{*}{ Niksar'da çözümlenmesi gereken en önemli sorun } & İşsizlik & 56 & 63,6 \\
\hline & Altyap1 & 19 & 21,6 \\
\hline & Trafik & 12 & 13,6 \\
\hline & Çevre Kirliliği & 1 & 1,2 \\
\hline \multirow{2}{*}{ Niksar'ın Sakin Şehir unvanına sahip olmasını isteme } & Evet & 84 & 95,5 \\
\hline & Hayır & 4 & 4,5 \\
\hline \multirow{4}{*}{ Niksar'da yerel kalkınmayı sağlama yolları } & Sanayileşme & 17 & 19,3 \\
\hline & Turizm & 30 & 34,1 \\
\hline & Yerel Değerler & 25 & 28,4 \\
\hline & Diğer & 16 & 18,2 \\
\hline \multirow{2}{*}{ Sürdürülebilir yerel kalkınma kavramını duyma } & Evet & 78 & 87,5 \\
\hline & Hayır & 10 & 11,4 \\
\hline
\end{tabular}

Katılımcıların \%64'ü Niksar'da çözümlenmesi gereken en önemli sorunun işsizlik olduğunu belirtmişlerdir. Niksar'da yerel kalkınmanın turizm ile olabileceğini düşünen katılımcıların oranı \%34, yerel değerlerin tanıtımı ile sağlanabileceğini düşünenlerin oranı \%28'dir. Bu oranların yüksek olması Cittaslow olduğu durumda turizm, yerel değerler ve yerel ürünler ile yeni ekonomik getirilerin oluşabileceği anlamına gelmektedir.

Katılımcıların \%87,5'i sürdürülebilir yerel kalkınma kavramını bildiğini ifade etmektedir. Yerel kalkınma kavramının bu düzeyde bilinmesi katılımcıların yöneltilen sorulara bilinçli bir şekilde cevap verdiklerini göstermektedir.

\section{Doğrulayıcı Faktör Analizi}

İstatistiksel olarak ölçeğin yapı geçerliliği tespiti için faktör analizi tekniği kullanılmıştır. İlk önce ölçeğin faktör analizine uygun olup olmadığını tespit etmek için KMO ve Bartlett testleri yapılmıştır. Örneklemin ne kadar büyüklükte olduğunu tespit etmek için KMO katsayısı hesabı yapılmaktadır. Bartlett testi ile faktör analizindeki evrenin dağılımının normal olup olmadığı belirlenmektedir. Bu durum için Bartlett küresellik test sonucunun istatistiki açıdan anlamlı olması gerekir. KMO testinin ölçüm sonucu 1000'e yakın olmalıdır. Bartlett küresellik testi de istatistiki açıdan anlamlı olmalıdır. Faktör analizi testinde faktörlere ölçek atanması veya ölçekten çıkarma için faktör yüküne bakılması gerekir. Maddelerin faktörler ile ilişkisini faktör yük değeri açıklar. Faktörlere ait yük değerinin yüksek olması beklenir. Maddelerin faktör yüklerinin 0,30'dan küçük olması veya her iki maddenin de faktör yüklerinin farkının 0,10 'dan az olması durumu söz konusu olduğunda madde ölçekten çıkartılarak analiz işlemine devam edilir.

Ölçeğe ait güvenirlik düzeyini Cronbach's alfa katsayısı verir. Bu kasayı 0 ile 1 arasında değişkenlik göstermektedir. Ölçeğe ait güvenirlilik testi alfa( $\alpha)$ katsayısına bağlı olarak yorumlaması şu şekilde yapılmaktadır (Nunnally, 1967: 248).

- $0,00 \leq \alpha<0,40$ olduğunda ölçek güvenilir değildir,

- $0,40 \leq \alpha<0,60$ olduğunda ölçeğin güvenirliği düşüktür,

- $0,60 \leq \alpha<0,80$ olduğunda ölçek oldukça güvenilirdir,

- $0,80 \leq \alpha<1,00$ olduğunda ölçek yüksek derecede güvenilir kabul edilir.

Sakin şehir hareketi algısı ölçeği için KMO ve Barlett Testi sonuçları Tablo 3'de verilmiştir. Uygulanan anketin analiz sonucuna göre ölçek için hesaplanan KMO değeri 0,89(KMO>0,500) olup Bartlett testi bu 
sonuca göre istatistiki olarak anlamlı bulunmuştur $(\mathrm{p}<0,05)$. Bu durumda ölçek faktör analizi için uygun bulunmuştur.

Tablo 3. KMO ve BarlettTesti (Sakin Şehir Hareketi Algısı Ölçeği)

\begin{tabular}{lcc}
\hline KMO & & 0,89 \\
\hline \multirow{3}{*}{ Bartlet Testi } & chi-square & 1007 \\
& Sd & 153 \\
& $\mathrm{P}$ & 0,00 \\
\hline
\end{tabular}

Sakin şehir hareketi algısı faktör analizi sonuçlarıTablo 4'de verilmiştir. Uygulanan faktör analizi sonuçlarına göre ölçeğin 3 alt boyuttan oluştuğu görülmektedir. Ölçeğe ait birinci kısım Sakin Şehir hareketinin doğal çevreye olan etkisi ile bağlantılı olan maddelerden oluşmaktadır. Doğal çevre boyutunda yer alan maddelerin faktör yükleri 0,576 ve 0,787 arasında değişmektedir. Doğal çevre boyutunun toplam varyansı açıklama oranı \%24,955'dir. Test sonucunda, Cronbach's Alfa katsayısı 0,817 olarak hesaplanmıştır. Alfa katsayısına bakıldığında boyutun güvenirlilik düzeyinin uygun olduğu gözlemlenmektedir.

Tablo 4:Sakin Şehir Hareketi Algısı Faktör Analizi Sonuçları

\begin{tabular}{|c|c|c|c|}
\hline Maddeler & [1] & [2] & [3] \\
\hline \multicolumn{4}{|l|}{ Doğal Çevre [ 1 ] } \\
\hline 19. Planlı yapılanmayı sağlar & 0,787 & & \\
\hline 21. Peyzaj çalışmalarını artırır & 0,576 & & \\
\hline 23. Kentin yenilenmesinde geleneksel mimariye bağlı kalınmasını sağlar & 0,658 & & \\
\hline 25. Kent içindeki yeşil alanların miktarını ve kalitesini artırır & 0,685 & & \\
\hline 26. Kent içindeki görsel kirliliğin azalmasını sağlar. & 0,687 & & \\
\hline
\end{tabular}

\section{Refah ve Ekonomi[ 2 ]}

30. Yerel ekonominin canlanmasını sağlar.

31. Bölge dışından gelen yatırımları artırır.

32. Halkın gelir düzeyini artırır

0,761

34. Yoksul ve dezavantajlı kesimlerin yaşam kalitesini artırır.

0,714

38. Niksar'dan göçü azaltır.

0,777

\section{Kültür[ 3 ]}

35. Kent içinde engelliler için geliştirilen projeleri artırır.

0,661

36. Organik tarımın gelişmesini sağlar.

0,685

37. Tarihi merkezlerin değerini artırır.

39. Geleneksel el sanatlarının üretimini artırır.

40. Yerel kültürel etkinliklerde artı̧s sağlar.

0,686

41. Kültürel değerlerin korunmasını sağlar

0,641

43. Bölgeye gelen turistlerin sayısını artırır.

44. Sosyal yaşamın gelişmesini sağlar.

0,673

\begin{tabular}{lccc}
\hline Açıllanan Varyans (\%) & 24,955 & 20,997 & 18,261 \\
\hline Cronbach's Alfa & 0,817 & 0,863 & 0,917 \\
\hline
\end{tabular}

Ölçeğe ait 2. boyut Sakin Şehir Hareketinin refah ve ekonomiye etkisi olan maddelerden oluşmaktadır. Bu boyutta yer alan maddelerin faktör yükleri 0,691 ve 0,777 arasında değişmektedir. Refah ve ekonomi boyutunun toplam varyansı açılama oranı ise \%20,997'dir.Analizde Cronbach's Alfa katsayısı 0,863 olarak hesaplanmıştır. Alfa katsayısına bakıldığında boyutun güvenirlilik düzeyinin çok yüksek olduğu görülmektedir.

Ölçeğe ait son ve üçüncü boyut ise Sakin Şehir Hareketinin Kültürel anlamda etkileri ile bağlantılı olan maddelerden oluşmaktadır. Bu boyutta bulunan maddelere ait faktör yük oranları 0,641 ve 0,738 arasında değişmektedir. Kültürel boyutun toplam varyansı açıklama oranı \%18,261 olarak hesaplanmıştır. Test sonucu Cronbach's Alfa katsayısı 0,917'dir. Alfa katsayısına bakıldığında boyutun güvenirlik düzeyinin son derece yüksek olduğu görülmüştür. Uygulanan analiz sonucunda 16, 17, 18, 20, 22, 24, 27, 28, 29, 33, 42, 45, 46. maddeler binişlilik ve farklı faktörde bulunduğu için analizden çıkartılmıştır. 
Tablo 5. KMO ve Barlett Testi(Sakin Şehir Algısı ve Destekleme Ölçeği)

\begin{tabular}{lcc}
\hline KMO & & 0,89 \\
\hline \multirow{3}{*}{ Bartlett Testi } & chi-sguare & 419,17 \\
& Sd & 15 \\
& $\mathrm{P}$ & 0,00
\end{tabular}

Sakin şehir algısı ve destekleme ölçeği KMO ve Barlett Testi sonuçları Tablo 5'de verilmiştir. Buna göre, ölçek için hesaplanan KMO değeri 0,89 $(\mathrm{KMO}>0,500)$ ve Bartlett testi istatistiksel olarak anlamlı bulunmuştur $(p<0,05)$. Ölçek faktör analizi için uygundur.

Tablo 6. Sakin Şehir Algısı ve Destekleme Faktör Analizi Sonuçları

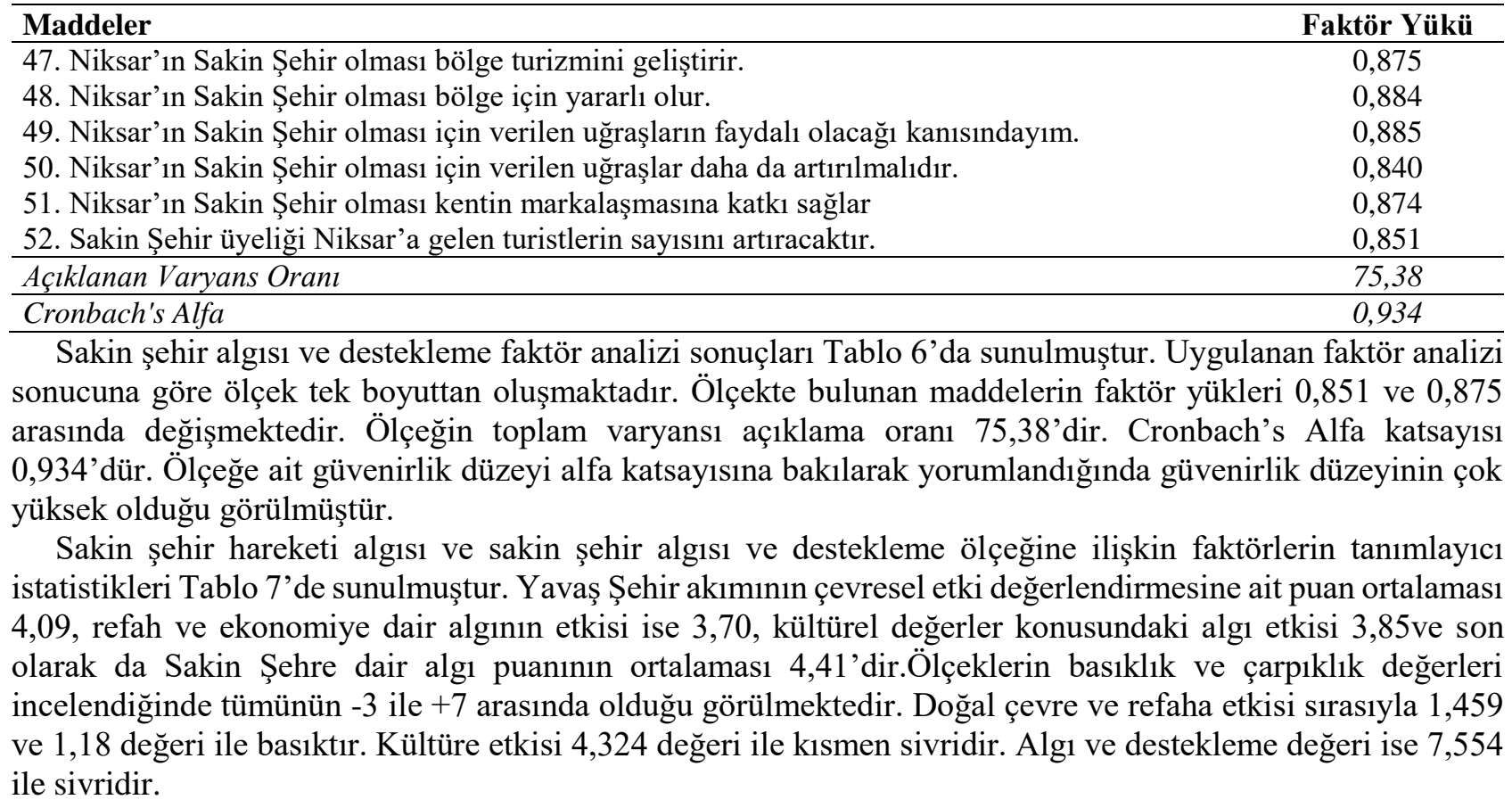

Tablo 7.Tanımlayıcı İstatistikler

\begin{tabular}{lccccc}
\hline Sakin Şehir hareketinin & N & Ortalama & Standart sapma & Çarpıklık & Basıklık \\
\hline Doğal çevreye etkisi & 88 & 4,09 & 0,68 & $-1,071$ & 1,459 \\
Refaha etkisi & 88 & 3,70 & 0,74 & $-0,713$ & 1,180 \\
Kültüre etkisi & 88 & 3,85 & 0,67 & $-1,461$ & 4,324 \\
Algı ve destekleme & 88 & 4,41 & 0,69 & $-2,280$ & 7,557 \\
\hline
\end{tabular}

Ölçeklerden elde edilen basıklık ve çarpıklık değerlerinin+7 ile -3 arasında olması normal dağılıma yakın olduğu için yeterli görülmektedir. Buna göre çalışmada ölçek puanlarının normal dağılıma uygun olduğu kabul edilmiş ve hipotez testlerinde parametrik testlerin kullanılmasına karar verilmiştir. Çalışmada Sakin Şehir Hareketi Algısının boyutları ile Sakin Şehir Algısı ve Destekleme arasındaki ilişki pearsonkorelasyon testi ile analiz edilmiş ve sonuçlar Tablo 8'de verilmiştir.

Tablo 8. Sakin Şehir Hareketi (SŞH) Algısı Boyutları İle Sakin Şehir Algısı ve Destekleme Arasındaki Korelasyon İlişkisi

\begin{tabular}{lcccc}
\hline & [ 1 ] & [ 2 ] & [ 3 ] & [ 4 ] \\
\hline Sakin Şehir Hareketinin Doğal Çevreye Etkisi[ 1 ] & 1 & & & \\
Sakin Şehir Hareketinin Refaha Etkisi[ 2 ] & 0,555 & 1 & & \\
Sakin Sehir Hareketinin Kültürel Etkisi[ 3 ] & 0,653 & 0,632 & 1 & \\
Sakin Şehir Algis1 ve Destekleme[ 4 ] & 0,626 & 0,676 & 0,707 & 1 \\
\hline
\end{tabular}

Not: Tüm ilişkiler \%1 önem düzeyinde istatistiki olarak anlamlıdır.

Yapılan analiz sonucuna göre Sakin Şehir alg1 ve destekleme ile çevre etkisi arasında pozitif yönde orta derecede kuvvete sahip bir ilişki bulunmaktadır $(\mathrm{r}=0,626 ; \mathrm{p}<0,05)$. Sakin Şehri Algı ve destekleme ile refaha 
etki arasında pozitif yönlü orta derecede kuvveti olan ilişki bulunmaktadır ( $r=0,676 ; p<0,05)$. Sakin Şehir alg1 ve desteklemesi ile kültürel etki arasında pozitif yönde olan orta kuvvete sahip etki vardır ( $r=0,707 ; p<0,05)$.

Sakin şehir algısının boyutları ve sakin şehir algısı ve desteklemenin yaşa, cinsiyete, eğitim düzeyine ve Niksar' da ikamet süresine göre anlamlı bir farklılık gösterip göstermediği ANOVA ve t-testi analiz edilmiştir. Analiz sonuçlarına göre, Niksar'da yaşayan kişilerin Sakin Şehir Algısı ve Destekleme durumları eğitim düzeylerine göre ve yine Niksar'da yaşayan kişilerin Sakin Şehir Hareketinin Doğal Çevreye Etkisi algılarının gelir seviyelerine göre istatistiki olarak anlamlı farklılık gösterdiği tespit edilmiştir. Lise mezunu olanların Sakin Şehir algısının en yüksek, Ön Lisans mezunu olanların ise Sakin Şehir algısının en düşük olduğu söylenebilir. Bireylerin gelir düzeyi arttıkça Sakin Şehir hareketinin doğal çevreye etkisine dair algının arttığı sonucuna ulaşılmıştır.

\section{SONUÇ}

Yerel düzeyde sosyal, ekonomik ve ekolojik toparlanmalar için Cittaslow, hızlı yaşam kavramına karşı çıkmıştır. Yavaş Şehir standartlarında, özgün olan yapı ve doğa korunarak sürdürülebilir bir ekonomi ve yaşam biçiminin sağlanabileceği düşüncesi hakimdir.

Çalışmada Niksar ilçesinin Cittaslow kriterleri açısından değerlendirilmesi yapılmıştır. Niksar ilçe nüfusunun 50.000'in altında olması önemli kriterlerden birisidir. Değerlendirmeye göre 72 kriterden 22 adetinde konu ile ilgili çalışma bulunmayıp, 50 adetinde ise plan, proje ve uygulanan çalışmalar bulunmaktadır. Cittaslow komitesi başvuru dosyasında \% 50 oranında olumlu kriter aramaktadır. Bu araştırma kapsamında yapılan değerlendirmede Niksar ilçesi kriterlerin \%69'unu karşıladığı tespit edilmiştir. Yapılan ön değerlendirmede Niksar İlçesi pozitif potansiyele sahiptir.

Niksar halkının Sakin Şehir konusundaki görüşlerini belirlemek için anket çalışmasında çevresel, kültürel ve ekonomik gelişimi tespit etmeye yönelik alan araştırması yapılmıştır. Araştırma sonucunda; Sakin Şehir kavramını bilme düzeyi yüksektir, katılımcıların büyük çoğunluğu Sakin Şehir kavramını önceden duymuşlardır. Niksar'ın Sakin Şehir unvanına sahip olmasını isteyenlerin oranı yüksektir. Niksar'da en önemli sorununun işsizlik olduğu tespit edilmiştir. Yerel düzeyde kalkınmanın turizm ve yerel değerler ile sağlanacağını ifade edenler çoğunluktadır. Niksar'da yaşayan kişilerin Sakin Şehir algısı ve destekleme durumları eğitim ve gelir seviyelerine göre anlamlı bir farklılık gösterdiği tespit edilmiştir. Niksar'ın Sakin Şehir olması durumunda kentin ve yakın çevredeki bölgelerin bu ortaklık ve üyelikten birçok açıdan kazanım sağlaması mümkün olacaktır. Kentin markalaşması ile sosyal, ekonomik ve çevresel kazanımlar artacak bununla birlikte sürdürülebilir yerel kalkınmaya katkı sağlayacaktır. Kentin marjinal biçimde isminin uluslararası platformda anılması ve Cittaslow üyesi olmanın gerektirdiği çalışmaları ile birlikte kent potansiyelini ön plana çıkartarak yeni bir cazibe merkezine dönüşecektir. Türkiye'de yavaş akımı için uygulanan plan ve projelerin ilgili kurumlarca sürüncemeye bırakılmadan dikkate alınarak desteklenmesi gerekmektedir. Kurumlar organize olarak, gerekli ve yeterli desteği Niksar Belediyesine vermelidir. Kentlerin farklı kimlik kazanmaları amacıyla ulusal ve uluslararası çapta yavaş çalışmaları daha fazla artırılarak kentlerin ekonomik potansiyelleri harekete geçirilebilir. 


\section{KAYNAKLAR}

Acar, Y. (2016). Turistlerin Sakin Şehirleri Tercih Nedenleri, Memnuniyet Düzeyleri ve Tekrar Ziyaret Etme Niyetleri; Türkiye'deki Sakin Şehirlerin Değerlendirilmesi, Aksaray Üniversitesi Sosyal Bilimler Enstitüsü.

Acuner, E. (2014). Çamlıhemşin için Cittaslow Model Önerisi: Karşılaştırmalı Bir Analiz, Doktora Tezi.

Akgül,U.(2010). Sürdürülebilir Kalkınma: Uygulamalı Antropolojinin Eylem Alanı. Ankara Üniversitesi Dil ve Tarih Coğrafya Fakültesi, Antropoloji Dergisi, 24:133-164.

Casanova, F. (2004).Local Development, Productive Networks and Training: Alternative Approaches to Training and Work for Young People, ILO.

Çakıcı, A,, Yenipınar, U. ve Benli, S. (2015). Yavaş Şehir Hareketi: Seferihisar Halkının Tutum ve Algıları İle Yaşam Doyumları. Seyahat ve Otel İşletmeciliği Dergisi, 11(3).

Çahantimur, A.ve Yıldız, H. T. (2008). Sürdürülebilir Kentsel Gelişmeye Sosyokültürel Bir Yaklaşım: Bursa Örneği. İTÜ Dergisi, Mimarlık, Planlama, Tasarım, 7(2).

ÇARKÇI, A. (2008). Ulusal Kalkınma İçin Yerel Teklifler. Şehir Yayınları: İstanbul.

Çiçek, D. (2017).Bir Kalkınma Modeli Olarak Sakin Şehirlerde Yerel Halkın Turizm Desteği: Ege - Marmara Bölgesi Örneği, Doktora Tezi.

Doğrusoy, I.T. ve Dalgakıran, A. (2011). An Alternati ve Approach in Sustainable Planning: Slow Urbanism. ArchnetIJAR, International Journal of Architectural Research, 5: 127-142.

Donat, O. (2016). Sakin Kent (Cittaslow) Üyeliğinin Kamusal Mekânlara Etkisi: Türkiye'deki Sakin Kentler Üzerine Bir İnceleme, Yüksek Lisans Tezi.

Erten, S. (2009). Cittaslow / Yavaş Şehir Seferihisar. Arredamento Mimarlık Dergisi, 9:106-109.

Eraydın, A. (2004). Bölgesel Kalkınma Kavram, Kuram ve Politikalarında Yaşanan Değişimler, Kentsel Ekonomik Araştırmalar, 1:126-146.

Fell, E. veLukianova, N. (2015). Fast Food and The Semiotics of Gastronomy. Journal for Communication Studies, 8 (2/16): 59-73.

Göker, H. (2020).Sürdürülebilir Kalkınmada Cittaslow (sakin kent) Modelinin Kentsel Çekim Gücü Üzerindeki Etkisi: Halfeti Örneği, Yüksek Lisans Tezi.

Hart, M. (1999). The Guide to Sustainable Community Indicators (2. Bask1). North Andover: Hart Environmental Data.

Hahnel, R. (2004). Siyasal İktisadın ABC'si, Modern Bir Yaklaşım, (Çev.:Y.Alagon), İstanbul, Ayrıntı Yayınları,1. Baskı: 1-70.

Hatipoğlu, B. (2015), 'Cittaslow': Quality of Life and Visitor Experiences, Tourism Planning Development, 12(1): 20 36.

Hekimci, F. (2014).Sürdürülebilir Bir Yerel Kalkınma Modeli: 'YYavaş Şehirler"' ve Ekoturizm. Kalkınmada Anahtar Verimlilik Dergisi, T.C. Bilim Sanayi Ve Teknoloji Bakanlığı Verimlilik Genel Müdürlüğü, Haziran 2014, Ankara. 4: 77 - 112.

Holmberg, J. Ve Sandbrook, R. (1992).Sustainable Development: What is to be done? Making Development Sustainable: Redefining Institutions, Policy and Economics. (Ed. J. Holmberg). International Institute for Environmentand Development, p. 19-38, Island Press, Washington, D. C.

Honore, C. (2008).Yavaş! Hız Çılgınlığına Başkaldıran Yavaşlık Hareketi, (Çev.:E.Gür), İstanbul. Alfa Yayınları,. Houghton JT Jenkins GJ Ephraums JJ, eds. 1990 Climate Change: The Scientific Assessment. Cambridge (UK), Cambridge University Press.

Juris, J. S. (2005).The New Digital Media and Activist Networking within Anti- Corporate Globalization Movements. The Annals, 7(1): 189-208.

Kadıŏlu, D.Y. (2009). Yavaşlığın Keyfi Bu Şehirlerde, Yolculuk Dergisi, 62:72-76, Elektronik Sürümü, www.yolculuk.com.tr/, 20.03.2020.

Karabă̆, Ö., Yücel, F. ve İnal, M. E. (2012). Cittaslow Movement: An Opportunity for Branding Small Towns and Economic Development in Turkey. International Journal of Economics and Research, 313: 64-75.

Kaya, E. (2007). Kent Yönetiminde Yeni Yaklaşım: Yerel Kalkınma Yönetimi Okutan

Yayınc1lı, İstanbul.

Kula, E. (1998). History of Environmental Economic Thought, Routledge, London.Larre, Dominique (1986), "Çevre Yönetimi Konulu Dünya Sanayi Konferansı'nın Sonuçları ve Tavsiye Kararları”, Sanayi ve Çevre Konferansı, TÇSV, Ankara, 26-29.

Lım, S. H. (2003). "Local Partnership and Human Resources Development", Paper prepared for KLI/ILO Tripartite Workshop on Skill Development, High Performance, Work Organization and Social Dialog, Seoul, Korea, (6 March), 1-28.

Lowry, L.L. ve Lee, M. (2011). CittaSlow, Slow Cities, Slow Food: Searching for a Model for the Development of Slow Tourism, Travel \& Tourism Research Association, 42nd Annual Conference Proceedings: Seeing the Forest and the Trees - Big Picture Research in a Detail- Driven World, June 19-21, 2011, London, Ontario, Canada.

Miele, M. (2008). Cittaslow: ProducingSlownessagainst the Fast Life, Space andPolity, 12(1): 135-156.

Öztürk, S. (2012). Small Towns Reshaping Their Urban Planning Policies Joining in the Cittaslow International Network: The Case of Seferihisar in Turkey, Ankara: Middle East Technical University The Graduate School of Social Sciences. 
Özmehmet, E. (2008). Dünya'da ve Türkiye'de Sürdürülebilir Kalkınma Yaklaşımları, Journal of Yaşar Üniversity, 3(12):1853-1876.

Pektaş, E. K. (2010), “Türkiye’de Sosyal Belediyecilik Uygulamaları ve Temel Sorunlar”, Sakarya Üniversitesi Sosyal Bilimler Enstitüsü Akademik İncelemeler Dergisi, 5(1): 1-114.

Pisani, J, A. (2006). Sustainable Development- Historical Roots of Concept, Environmental Sciences, 3(2): 83-96.

Presenza, A., Abbate, T., Perano, M., (2015). The Cittaslow Certification and its Effects on Sustainable Tourism Governance, Enlightening Tourism. A Pathmaking Journal, 5(1): 40-64.

Radstorm, S. (2011). IJPP Italian Journal of Planning Practice Vol.I, issue 12011.

Rodriguez-Pose, A. (2001). The Role of the ILO in Implementing Local Economic Development Strategies in a Globalized World, Working Papers, London, (31 December), 1-19.

Servon, L. J. ve Pink, S. (2015). Cittaslow: Going Glocal in Spain, Journal of Urban Affairs, 37(3): 327-340.

Sezgin, M. ve Ünüvar, Ş. (2011).Sürdürülebilirlik ve Şehir Pazarlaması Ekseninde Yavaş Şehir, Çizgi Kitabevi: Konya

Sungur, Z. (2013), “Türkiye'nin Sakin Şehirlerindeki Kadın Girişimciliğine Sosyolojik Bir Bakış”, International Conference on Eurasian Economies Session 3c: Girişimcilik, 17.02.2020.

Şenol, F.(2013).Türkiye Turizm Coğrafyası ve Dünya Kültürel Mirası (3 b.). Detay Yayıncılık: Ankara.

Ursulo Sto, T. Ve Unni, E. K. (2010). Case Studies in Sustainable Consumption and Production: Food And Agriculture. System Innovation for Sustainability, 3, Greenleaf Publishing, South Yorkshire, Great Britain, 6-44.

Ünal, Ç. (2016). Turizm Coğrafyasında Yeni Kavramlar "Yavaş Şehirler ve Yavaş Turizm”. Doğu Coğrafya Dergisi, 21(36): 13-28.

WCED, (1987). Our Common Future, Brundtland Report, Oxford \& New York: Oxford University Press.

Walter, L. (2009). Slow Food and Home Cooking: Toward a Relational Aesthetic of Food and Relational Ethic of Home, The Journal of The Center for Food in Community and Culture, 1(1): 1-23.

Yalçın A. ve Yalın S. (2013).Sürdürülebilir Yerel Kalkınma İçin Cittaslow Hareketi Bir Model Olabilir mi? Sosyal ve Beşeri Bilimler Dergisi, 5(1): 32-41.

Yazar, K. H. (2006). Sürdürülebilir Kentsel Gelişme Çerçevesinde Orta Ölçekli Kentlere Dönük Kent Planlama Yöntem Önerisi. Ankara: Yayınlanmamış Doktora Tezi, Ankara Üniversitesi Sosyal Bilimler Enstitüsü.

Yıldırım A ve Karaahmet A. (2013). Yavaş Şehir Hareketinin Kent İmajına Katkısı: Ordu-Perşembe Örneğinin Yerel Basın Üzerinden Analizi. Sosyal ve Beşeri Bilimler Dergisi, 5(1): 11-20.

Yurtseven, R. (2007). Slow Food ve Gökçeada: Yönetsel Bir Yaklaşım. Detay Yayıncılık: Ankara.

Zengin, E. , Başkurt, E. ve Es, M. (2014).Yerel Yönetimler ve Yerel Kalkınma, Manas Sosyal Araştırmalar Dergisi, 3(2): 95-124.

https://www.karsiyakahaber.com/yazarlar/opdr-serhan-celikhisar/germiyan-koyu-slow-food-ve-germiyan-festivali/2184

https://www.google.com/search?q=www.slowfood.com\&oq=WWW\&aqs=chrome.2.69i60j69i57j35i19i39j69i60j69i65 13j69i60.4252j0j4\&sourceid=chrome\&ie=UTF-8 (Erişim Tarihi:15.01.2020)

https://www.google.com/search?q=www.cittaslow.org\&oq=WWW.C\&aqs=chrome.2.69i60j69i57j35i39j0i512j0i457i5 12j0i51212j69i60.9520j0j4\&sourceid=chrome\&ie=UTF-8 (Erişim Tarihi: 20.01.2020).

https://www.google.com/search?q=www.niksar+belediyesi\&oq=www.niksar\&aqs=chrome.1.69i57j0i30.10591j0j9\&so urceid=chrome $\&$ ie $=U T F-8$ (Erişim Tarihi: 27.03.2020). 